\title{
Microcosmus exasperatus (Ascidiacea: Pyuridae), current distribution in the Mediterranean Sea
}

\author{
ALFONSO A. RAMOS-ESPLA ${ }^{1}$, ANDRES IZQUIERDO ${ }^{2}$ AND MELIH ERTAN ÇINAR ${ }^{3}$ \\ ${ }^{1}$ Departamento de Ciencias del Mar y Biologia Aplicada, Universidad de Alicante, 03080, Alicante, Spain, ${ }^{2}$ Centro de Investigación \\ Marina de Santa Pola (CIMAR), Universidad de Alicante-Ayuntamiento de Santa Pola, 03130 Santa Pola, Alicante, Spain, ${ }^{3}$ Ege \\ University, Faculty of Fisheries, Department of Hydrobiology, 35100 Bornova, İzmir, Turkey
}

\begin{abstract}
The presence of the pantropical ascidian Microcosmus exasperatus has been an object of some taxonomic confusion in the Mediterranean Sea. A closely related species, M. squamiger was previously reported in the north of Tunisia (in 1962) as M. exasperatus; it has spread to the western Mediterranean and the northern part of the Ionian Sea, whereas, the reliable report of M. exasperatus has been made more recently (in 1998) in the Gulf of Gabès (South Tunisia), and later studies have confirmed its presence in the eastern Mediterranean basin (Lebanon and Israel). The occurrence of this species in Izmir (Turkey) extends its distribution range to the Aegean Sea. At present, the distributions of both species of Microcosmus are not overlapping in the Mediterranean, suggesting a different route of entrance, probably by the maritime traffic (M. squamiger via the Strait of Gibraltar; and M. exasperatus via the Suez Canal). The discontinuity in the distribution of M. exasperatus in the Mediterranean is analysed and discussed.
\end{abstract}

Keywords: ascidians, Microcosmus spp., alien species, lessepsian migrants, Mediterranean Sea, Aegean Sea

Submitted 19 January 2013; accepted 6 June 2013

\section{INTRロDUCTION}

The Mediterranean Sea represents an interesting and special part of the Atlantic-Mediterranean region with tropical and warm temperate waters, mainly in summer and in the inshore areas (Ekman, 1953; Briggs, 1974). Moreover, it supports an intense maritime traffic, aquaculture activities and it has been connected with the Red Sea (Indo-Pacific region) across the Suez Canal that has facilitated the progressive introduction of a high number of alien species (Por, 1978; Zibrowius, 1991, 2002; Boudouresque, 1999; Galil, 2000, 2007; Boero, 2002; Streftaris et al., 2005; Zenetos et al., 2005, 2010). Among the alien species, the ascidians are particularly abundant in some areas (i.e. harbour environment) and the maritime traffic is one of the principal introduction vectors for these species (Millar, 1971; Monniot \& Monniot, 1983; Monniot et al., 1991; Lambert, 2001).

The species of Pyuridae are solitary ascidians with hard tunics (particularly the genera Herdmania, Microcosmus and Pyura) and they are widely spread around the world, mainly in tropical and subtropical waters (Van Name, 1945; Kott, 1985, 2002; Monniot et al., 2001; Lambert, 2002; Monniot, 2002). Two alien species of Microcosmus (M. squamiger Michaelsen, 1927 and M. exasperatus Heller, 1878) have been reported in the Mediterranean Sea. These species have very similar external and internal morphological characters, and therefore their specimens have been occasionally misidentified in the Mediterranean Sea. The small siphonal spines appear to be the more useful characteristic to distinguish these species (Kott, 1985; Monniot, 2002). Microcosmos squamiger widely spreads in the western Mediterranean basin, whereas $M$. exasperatus has been only reported from some areas in the eastern Mediterranean (Turón et al., 2007; Izquierdo-Muñoz et al., 2009). New records of $M$. exasperatus confirm its presence in the Gulf of Gabès (Méliane, 1998) and extend its geographical distribution to the Aegean Sea. The discontinuity in the actual geographical distribution of $M$. exasperatus and the historical records of both species (with $M$. squamiger) are analysed and discussed.

\section{MATERIALS AND METHDDS}

Specimens of Microcosmus exasperatus were sampled (Table 1) from some localities in the Gulf of Gabès (south of Tunisia) and the Alsancak Harbour (Izmir Bay, Turkey). The Tunisian specimens $(\mathrm{N}=37)$ were collected during the project 'Biodiversity of the Gulf of Gabès (Tunisia)' by SCUBA/snorkel diving inside harbours (o-12 $\mathrm{m}$ depth), and by sledge-dredge $(10-25 \mathrm{~m}$ depth) and bottom trawling $(>25 \mathrm{~m}$ depth) on degraded Posidonia oceanica (Linnaeus) Delile, 1813 meadows and muddy detritic bottoms. One specimen from Izmir was collected on the mussel Mytilus galloprovincialis Lamarck, 1819 by scraping off an area of $400 \mathrm{~cm}^{-2}$ (Çinar et al., 2008). Previously, two specimens from Beirut airport piers (collection date: 2002, by H. Zibrowius) were identified by one of us (A.A.R.E.). 
Table 1. Sampled stations of Microcosmus exasperatus in the Mediterrranean Sea.

\begin{tabular}{|c|c|c|c|c|c|}
\hline Locality & Coordinates & Depth (m) & Date & SM & Observations \\
\hline Alsancak Harbour (Izmir Bay, Turkey) & $\mathrm{N}_{3} 8^{\circ} 26^{\prime} 38^{\prime \prime}-\mathrm{E}_{2} 7^{\circ} 08^{\prime} 54^{\prime \prime}$ & 0.2 & 01.2004 & Sk & Fouling community \\
\hline Southern Kerkennah Islands (Tunisia) & $\mathrm{N}_{34}{ }^{\circ} 35^{\prime} 22^{\prime \prime}-\mathrm{E}_{11}{ }^{\circ} 18^{\prime} 39^{\prime \prime}$ & $23-25$ & 18.07 .09 & $\mathrm{SD}$ & Degraded Posidonia meadows \\
\hline Skhira Harbour (Tunisia) & $\mathrm{N}_{34}{ }^{\circ} 18^{\prime} 23^{\prime \prime}-\mathrm{E}_{1} 0^{\circ} \mathrm{og}^{\prime} 21^{\prime \prime}$ & $1-10$ & 31.07 .09 & Sc & Fouling community \\
\hline Western Djerba Island (Tunisia) & $\mathrm{N}_{33}{ }^{\circ} 59^{\prime} 12^{\prime \prime}-\mathrm{E}_{10} 0^{\circ} 39^{\prime} 54^{\prime \prime}$ & $13-15$ & 19.07 .10 & $\mathrm{SD}$ & Posidonia dead matte \\
\hline Western Djerba Island (Tunisia) & $\mathrm{N}_{33}{ }^{\circ} 56^{\prime} 51^{\prime \prime}-\mathrm{E}_{10} 0^{\circ} 38^{\prime} 17^{\prime \prime}$ & $14-15$ & 21.07 .09 & $\mathrm{SD}$ & Posidonia dead matte \\
\hline Western Djerba Island (Tunisia) & $\mathrm{N}_{33}{ }^{\circ} 56^{\prime} 16^{\prime \prime}-\mathrm{E}_{10}{ }^{\circ} 42^{\prime} 38^{\prime \prime}$ & $9-10$ & 21.07 .09 & SD & Posidonia dead matte \\
\hline Eastern Djerba Island (Tunisia) & $\mathrm{N}_{33}{ }^{\circ} 50^{\prime} 40^{\prime \prime}-\mathrm{E}_{11}{ }^{\circ} 12^{\prime} 22^{\prime \prime}$ & $34-36$ & 23.07 .09 & BT & Muddy detritic bottom \\
\hline Zarzis Harbour (Tunisia) & $\mathrm{N}_{33}{ }^{\circ} 29^{\prime} 06^{\prime \prime}-\mathrm{E}_{11}{ }^{\circ} 07^{\prime} 04^{\prime \prime}$ & $1-2$ & 26.07 .09 & Sk & Fouling community \\
\hline
\end{tabular}

SM, sampling method; SD, sledge-dredge; BT, bottom trawl; Sc, SCUBA diving; Sk, snorkelling.

The identification was made according to Kott (1985). The siphonal spines were extracted from the inhalant siphon and observed by dissecting microscope. Some scanning electron microscopy pictures were taken, after covering the dry spinules with gold. The material is deposited at the Institute National des Sciences et Technologies de la Mer (Salammbô, Tunisia), the Marine Research Centre of Santa Pola (University of Alicante, Spain: codes GG200901-07, GG201001-03 and AH200401) and the Museum of Faculty of Fisheries (Ege University, Turkey).

\section{RESULTS AND DISCUSSIDN}

All specimens have a globular and irregular shape with the siphons, more or less prominent (Figure 1); the colour is brown, and some individuals have small epibionts (i.e. rhodophytes, foraminifers and serpulids) on the tunic. The smallest specimen (12 mm long) was found in Alsancak Harbour (January); and the sizes of the Tunisian specimens ranged between 15 and $35 \mathrm{~mm}$ (July). The siphonal spines (Figure 2) are curved ('shark-fin like', Kott, 1985) and about $50 \mu \mathrm{m}$ in length. The gonads of the smaller specimen were not fully developed; whereas the specimens from the Gulf of Gabès had well-developed gonads.

The individuals were not aggregated, and only small groups of 3-5 specimens were observed on dead Posidonia oceanica rhizomes. Some of the specimens were sampled on artificial substrata (concrete piers and harbours) in shallow waters (o-10 m depth), others on benthic habitats drastically influenced by trawling (Posidonia meadows and muddy detritic bottoms). In the degraded $P$. oceanica meadows (9-25 m depth), some shoots have still alive leafs, but the majority are dead matte with the alien bivalve Pinctada radiata (Leach, 1814). In muddy detritic bottoms (34-36 m depth), the ochrophyte Arthrocladia villosa (Hudson) Duby, 1830 and some rhodoliths are present. In the previous studies (Méliane, 2002; Bitar et al., 2007; Shenkar, 2008; Izquierdo-Muñoz et al., 2009; Shenkar \& Loya, 2009), specimens of Microcosmus exasperatus were also collected mainly on artificial substrates (concrete reefs, piers, harbours and plastic nets).

This opportunistic species colonized altered or degraded communities, often forming monospecific aggregations (Rius et al., 2009). Although, M. exasperatus was observed in natural shallow rocky habitats in Israel (Shenkar \& Loya, 2009), the community was impoverished with the dominance of the calcareous red algae (Amphiroa, Jania, Corallina,

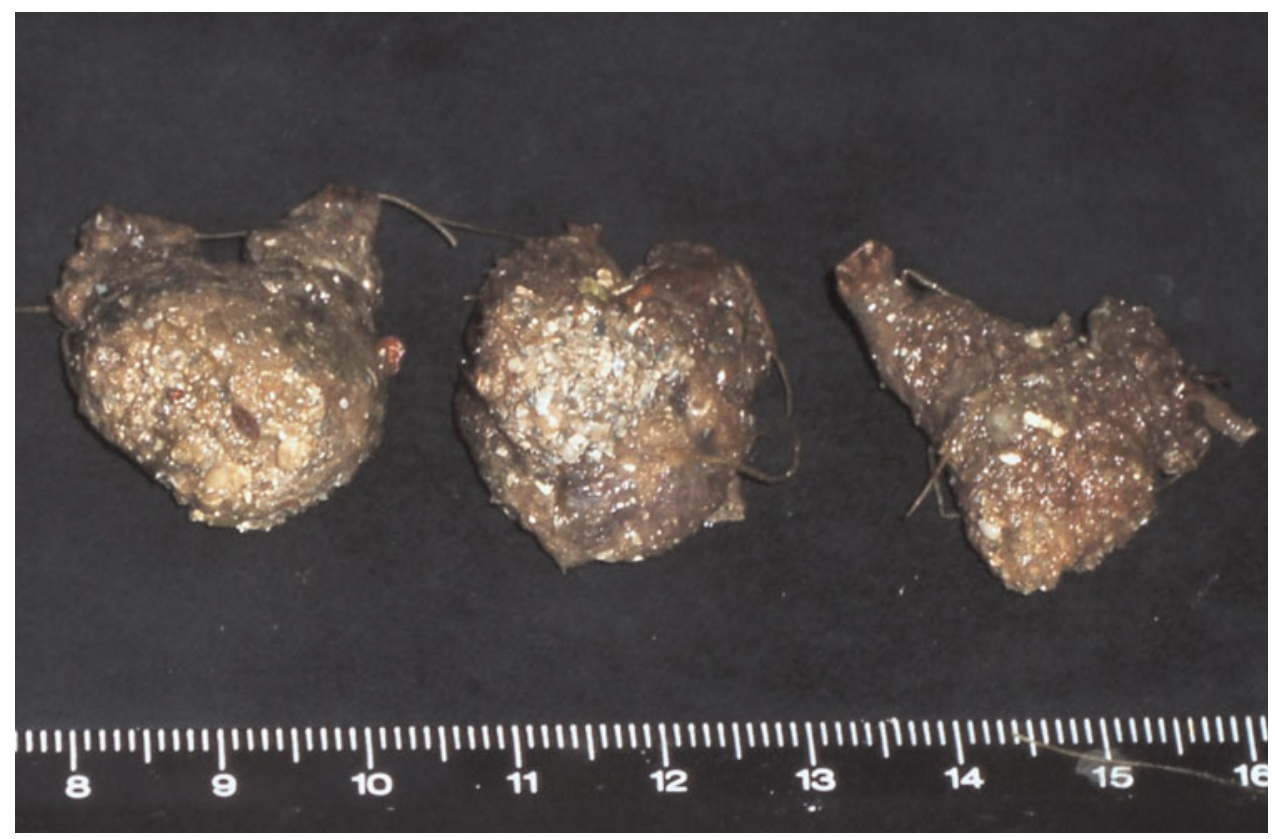

Fig. 1. Microcosmus exasperatus from south of Kerkennah (Tunisia) sampled by dredge, $23-25 \mathrm{~m}$ depth on dead Posidonia oceanica matte. 

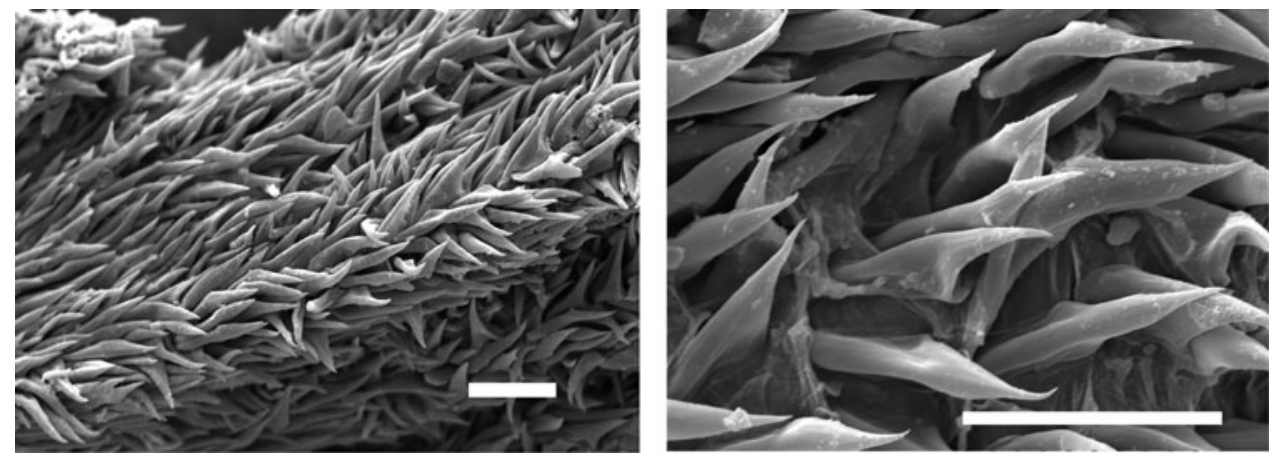

Fig. 2. Siphonal spines of Microcosmus exasperatus from Alsancak Harbour. Scale bars: $50 \mu \mathrm{m}$.

Lithophyllum and Neogoniolithon), due to the high herbivorous pressure (Siganus spp., Sparisoma cretense (Linnaeus, 1758), Conomurex persicus (Swainson, 1821)). The area was also degraded by bottom trawling.

Microscomus exasperatus, was first recorded from Djerba Island (south of Tunisia) in 1998 (Méliane, 2002), and then it was observed on the coasts of Lebanon and Israel (Bitar et al., 2007; Turón et al., 2007; Shenkar, 2008; Izquierdo-Muñoz et al., 2009; Shenkar \& Loya, 2009) in the eastern Mediterranean (Table 2). With regards to $M$. squamiger, it was first reported from northern Tunisia (identified as M. exasperatus) in 1962 (Monniot, 1981). Afterwards, M. squamiger was observed around the western Mediterranean and the Atlantic adjacent waters (Turón, 1987; Ramos-Esplá, 1988; Ramos-Esplá et al., 1993; Naranjo, 1995; Mastrototaro \& Dappiano, 2005; Turón et al., 2007), and the northern part of the Ionian Sea (Monniot, 1981; Mastrototaro et al., 2004; Izquierdo-Muñoz et al., 2009) (Figure 3).

The distribution of $M$. exasperatus in the eastern Mediterranean basin (Figure 3) appears to be discontinuous, occurring in three areas (Gulf of Gabès, Levantine coasts and eastern Aegean Sea). The occurrence of this species along the Mediterranean coast of Israel and southern Lebanon (airport piers of Beirut) is more or less continuous (Shenkar \& Loya, 2009), but not in northern Lebanon, as this species has not been observed in natural habitats (e.g. Ras Chekka and Anfeth; A.A.R.E., personal observation). On the other hand, it seems to be isolated at the location in the eastern Aegean Sea (Izmir Bay), as it was not found in previous studies performed along the Turkish coast (Çinar et al., 2006, 2011).
At present, no $M$. exasperatus record has been made from the northern-central Ionian and western Aegean areas (Italy, Greece, Malta and eastern Tunisia). The introduction vector for the spread of this species within the Mediterranean Sea could have been by the maritime traffic through commercial harbours between the Gulf of Gabès and Izmir Bay (Skhira and Zarzis in Tunisia and Alsancak in Turkey). It is the first time that an alien ascidian (M. exasperatus) has been reported from the Turkish coast of the Aegean Sea. In the previous studies (Çinar et al., 2006, 2011), three alien ascidians (Phallusia nigra Savigny, 1816, Symplegma brakenhielmi (Michaelsen, 1904) and Herdmania momus (Savigny, 1816)) were reported from the Levantine coast of Turkey. Kondilatos et al. (2010) and Thessalou et al. (2012) also observed P. nigra on the south-eastern coast of Rhodes and the Peristera Island in Greece, respectively.

Comparing the present distributions of the two alien Microcosmus in the Mediterranean Sea, it appears that their geographical areas are not overlapping and the colonization of $M$. exasperatus seems to be more recent than $M$. squamiger (Figure 3). Microcosmus squamiger occurs in the western Mediterranean and the northern part of the Ionian Sea, whereas $M$. exasperatus has become well established in the eastern Mediterranean basin (Levantine Sea) and the Gulf of Gabès (southern Ionian Sea). These findings might indicate that two different routes of colonizations are possible: one from the Atlantic through the Strait of Gibraltar (for M. squamiger); and another from the Indo-Pacific region through the Suez Canal (for M. exasperatus). The historical record might also suggest that the initial establishments of both species

Table 2. Records of Microcosmus exasperatus from the Mediterranean Sea.

\begin{tabular}{|c|c|c|c|}
\hline Locality & Year & Reported & Observations \\
\hline Western Djerba Island (Tunisia) & 1998 & Méliane (2002) & On concrete artificial reef \\
\hline Beirut Airport piers (Lebanosn) & 2002 & Identified by A.A.R.E. & Collection Zibrowius \\
\hline Beirut Airport piers (Lebanon) & 2005 & Izquierdo-Muñoz et al., 2009 & Fouling community \\
\hline Beirut (Lebanon) & - & Turon et al., 2007 & $\begin{array}{l}\text { Muséum National d'Histoire Naturelle, } \\
\text { Paris collections }\end{array}$ \\
\hline $\begin{array}{l}\text { Hadera, Shiqmona, Akko, Mikhmoret, } \\
\text { Achziv (Israel) }\end{array}$ & $2005-2006$ & $\begin{array}{l}\text { Shenkar, 2008; Shenkar } \\
\text { \& Loya, } 2009\end{array}$ & $\begin{array}{l}\text { Fouling community and natural } \\
\text { rocky shore }\end{array}$ \\
\hline Alsancak Harbour (Turkey) & 2004 & Present study & Fouling community \\
\hline Southern Kerkennah Islands (Tunisia) & 2009 & Present study & Degraded Posidonia meadows \\
\hline Eeastern Djerba Island (Tunisia) & 2009 & Present study & Detritic with Arthrocladia villosa \\
\hline Skhira Harbour (Tunisia) & 2009 & Present study & Fouling community \\
\hline Zarzis Harbour (Tunisia) & 2009 & Present study & Fouling community \\
\hline Western Djerba Island (Tunisia) & $2009-2010$ & Present study & Posidonia dead matte \\
\hline
\end{tabular}




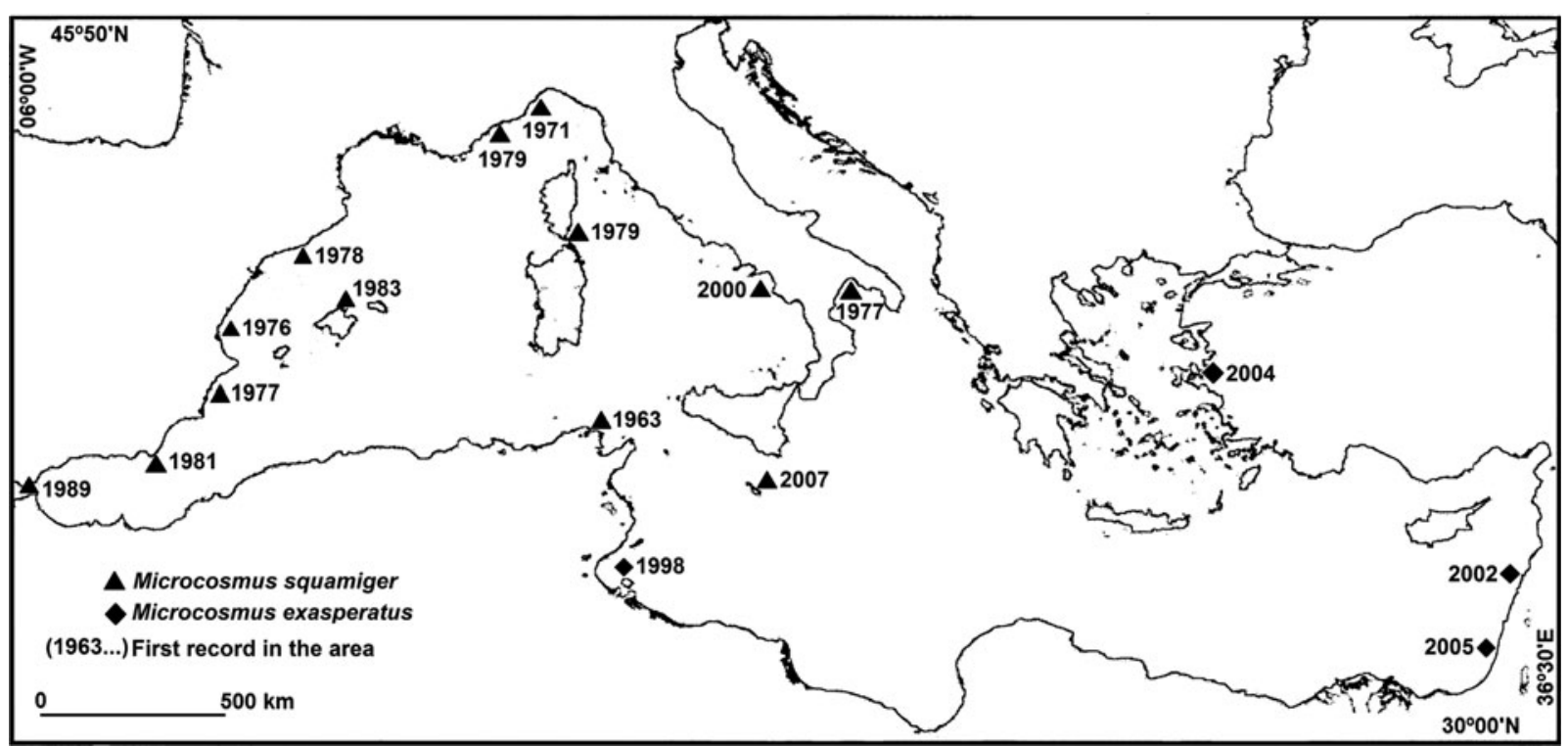

Fig. 3. Geographical distribution of the Microcosmus squamiger (triangles) and M. exasperatus (rhombus) in the Mediterranean Sea, with the first record/year of the species (from different sources; see text).

took place in the central Mediterranean, and that they have successfully expanded their distributional ranges to the western and eastern parts of the Mediterranean. This kind of spread might have been mediated by maritime traffic and/or current regimes in the area. Furthermore, different ecological conditions between the eastern and western Mediterranean basins (Pérès, 1967) could have affected their distributional patterns.

No discernible negative effect of $M$. exasperatus on the ecosystem and economy has been reported from the area so far. It is possible that this species could create problems in prevailing ecosystems and man-made structures, like other invasive ascidian species (see Lambert, 2007). However, the ecological and distributional features of this species in the area should be investigated and monitored to assess its possible impacts on the Mediterranean ecosystems.

\section{ACKNOWLEDGEMENTS}

The authors thank Helmut Zibrowius for collecting the ascidians samples from the CEDRE project in Lebanon; Ghazi Bitar, Maite Vázquez, Carlos Valle and Oscar Ocaña for their assistance in the field work; and two anonymous referees for their useful suggestions.

\section{FINANCIAL SUPPDRT}

This work was partly supported by the Scientific Research Projects of Ege University (Project number: 03 SUF 005).

\section{REFERENCES}

Bitar G., Ocaña O. and Ramos-Esplá A.A. (2007) Contribution of the Red Sea alien species to structuring some benthic biocenosis in the Lebanon coast (Eastern Mediterranean). Rapports de la Commission International pour l'Exploration de la Mer Méditerranée 38, 437.
Boero F. (2002) Ship-driven biological invasions in the Mediterranean Sea. CIESM Workshop Monographs 20, 87-91.

Boudouresque C.F. (1999) The Red Sea-Mediterranean link: unwanted effects of canals. In Sandlund O.T., Scheil P.J. and Viken A. (eds) Invasive species and biodiversity management. London: Kluwer Academic Publishers, pp. 213-228.

Briggs J.C. (1974) Marine zoogeography. New York: McGraw-Hill.

Cinar M.E., Bilecenoglu M., Öztürk B. and Can A. (2006) New records of alien species on the Levantine coast of Turkey. Aquatic Invasions 1, $84-90$.

Çinar M.E., Katagan T., Koçak F., Öztürk B., Ergen Z., Kocatas A., Önen M., Kirkim F., Bakir K., Kurt G., Dagli E., Açik S., Dogan A. and Özcan T. (2008) Faunal assemblages of the mussel Mytilus galloprovincialis in and around Alsancak Harbour (Izmir Bay, eastern Mediterranean) with special emphasis on alien species. Journal of Marine Systems 71, 1-17.

Çinar M.E., Bilecenoglu M., Öztürk B., Katağan T., Yokeș M.B., Aysel V., Dağlı E., Açı S., Özcan T. and Erdoğan H. (2011) An updated review of alien species on the coasts of Turkey. Mediterranean Marine Science 12, 257-315.

Ekman S. (1953) Zoography of the sea. London: Sidgwick \& Jackson.

Galil B.S. (2000) A sea under siege-alien species in the Mediterranean. Biological Invasions 2, 177-186.

Galil B.S. (2007) Seeing red: alien species along the Mediterranean coast of Israel. Aquatic Invasions 2, 281-312.

Izquierdo-Muñoz A., Díaz-Valdés M. and Ramos-Esplá A.A. (2009) Recent non-indigenous ascidians in the Mediterranean Sea. Aquatic Invasions 4, 59-64.

Kondilatos G., Corsini-Foka M. and Pancucci-Papadopoulou M.A. (2010) Occurrence of the first non-indigenous ascidian Phallusia nigra Savigny, 1816 (Tunicata: Ascidiacea) in Greek waters. Aquatic Invasions $5,181-184$.

Kott P. (1985) The Australian Ascidiacea. Part 1. Phlebobranchia and Stolidobranchia. Memoirs of the Queensland Museum 23, 1-440. 
Kott P. (2002) The genus Herdmania Lahille, 1888 (Tunicata, Ascidiacea) in Australian waters. Zoological Journal of the Linnean Society 134, $359-374$

Lambert G. (2001) A global overview of ascidian introductions and their possible impact on the endemic fauna. In Sawada H., Yokosawa H. and Lambert C.C. (eds) The biology of ascidians. Tokyo: Springer-Verlag, pp. 249-257.

Lambert G. (2002) Nonindigenous ascidians in tropical waters. Pacific Science 56, 291-298.

Lambert G. (2007) Invasive sea squirts: a growing global problem. Journal of Experimental Marine Biology and Ecology 342, 3-4.

Mastrototaro F. and Dappiano M. (2005) New record of the nonindigenous species Microcosmus squamiger (Ascidiacea: Stolidobranchia) in the harbour of Salerno (Tyrrhenian Sea, Italy). Marine Biodiversity Records e12, 1-3. doi: http://dx.doi.org/10.1017/ S1755267205001247.

Mastrototaro F., Petrocelli A., Cecere E. and Matarrese A. (2004) Non-indigenous species settle down in the Taranto Seas. Biogeographia 25, 47-54.

Méliane I. (2002) Contribution to the knowledge of the ascidian fauna in the south-east of Tunisia. MSc thesis. University of Alicante, Spain.

Millar R.H. (1971) The biology of ascidians. Advances in Marine Biology 9, $1-100$.

Monniot C. (1981) Apparition de l'ascidie Microcosmus exasperatus dans les ports méditerranéens. Téthys 10, 59-82.

Monniot C. (2002) Stolidobranch ascidians from the tropical western Indian Ocean. Zoological Journal of the Linnean Society 135, 65-120.

Monniot C. and Monniot F. (1983) Navigation ou courants? La colonisation des Açores et des Bermudes par les ascidies (Tuniciers benthiques). Comptes Rendus des Séances de la Société de Biogéographie 59, $53-58$.

Monniot C., Monniot F. and Laboute P. (1991) Coral reef ascidians of New Caledonia. Paris: Collection Faune Tropicale 30, ORSTOM, 247 pp.

Monniot C., Monniot F., Griffiths C.L. and Schleyer M. (2001) South African ascidians. Annals of the South African Museum 108, 1-141.

Naranjo S. (1995) Taxonomía, zoogeografía y ecología de las ascidias del Estrecho de Gibraltar. Implicaciones de su distribución bionómica en la caracterización ambiental de áreas costeras. $\mathrm{PhD}$ thesis. University of Seville, Spain.

Pérès J.M. (1967) Mediterranean benthos. Oceanography and Marine Biology: an Annual Review 5, 449-533.

Por F.D. (1978) Lessepsian migration. The influx of Red Sea biota into the Mediterranean by way of the Suez Canal. Berlin: Springer-Verlag.

Ramos-Esplá A.A. (1988) Ascidias litorales del Mediterráneo Ibérico. Faunistica, ecología y biogeografía. $\mathrm{PhD}$ thesis. University of Barcelona, Spain

Ramos-Esplá A.A., Buencuerpo V., Vázquez E. and Lafargue F. (1993) Distribución bionómica de las ascidias litorales del Estrecho de Gibraltar (sector ibérico). Publicaciones Especiales del Instituto Español de Oceanografía 11, 185-191.

Rius M., Pineda M.C. and Turón X. (2009) Population dynamics and life cycle of the introduced ascidian Microcosmus squamiger in the Mediterranean Sea. Biological Invasions 11, 2181-2194.
Shenkar N. (2008) Ecological aspects of the ascidian community along the Israeli coasts. $\mathrm{PhD}$ thesis. University of Tel-Aviv, Israel.

Shenkar N. and Loya Y. (2009) Non-indigenous ascidians (Chordata: Tunicata) along the Mediterranean coast of Israel. Marine Biodiversity Records e166, 1-7. doi:10.1017/S175526720999075.

Streftaris N., Zenetos A. and Papathanassiou E. (2005) Globalisation in marine ecosystems: the story of non-indigenous marine species across European Seas. Oceanography and Marine Biology: an Annual Review $43,419-453$.

Thessalou M., Aydogan Ö., Bekas P., Bilge G., Boyaci Y.O., Brunelli E., Circosta V., Crocetta F., Durucan F., Erdem M., Ergolavou A., Filiz H., Fois F., Gouva E., Kapiris K., Katsanevakis S., Kljajic Z.,. Konstantinidis E., Konstantinou G., Koutsogiannopoulos D., Lamon S., Macic V., Mazzette R., Meloni D., Mureddu A., Paschos I., Perdikaris C., Piras F., Poursanidis D., Ramos-Esplá A.A., Rosso A., Sordino P., Sperone E., Sterioti A., Taskin E., Toscano F., Tripepi S., Tsiakkiros L. and Zenetos A. (2012) New Mediterranean biodiversity records (December 2012). Mediterranean Marine Science 13, 312-327.

Turón X. (1987) Estudio de las ascidias de las costas de Cataluña e Islas Baleares. PhD thesis. University of Barcelona, Spain.

Turón X., Nishikawa T. and Rius M. (2007) Spread of Microcosmus squamiger (Ascidiacea: Pyuridae) in the Mediterranean Sea and adjacent waters. Journal of Experimental Marine Biology and Ecology 342, $185-188$.

Van Name W.G. (1945) The North and South American ascidians. Bulletin of the American Museum of Natural History 84, 1-476.

Zenetos A., Cinar M.E., Pancucci-Papadopoulou M.A., Harmelin J.G., Furnari G., Andaloro F., Bellou N., Streftaris N. and Zibrowius H. (2005) Annotated list of marine alien species in the Mediterranean with records of the worst invasive species. Mediterranean Marine Science 6, 63-118.

Zenetos A., Gofas S., Verlaque M., Çinar M.E., Garcia Raso J.E., Bianchi C.N., Morri C., Azzurro E., Bilecenoglu M., Froglia C., Siokou I., Violanti D., Sfriso A., San Martin G., Giangrande A., Katağan T., Ballesteros E., Ramos-Esplá A., Mastrototaro F., Ocaña O., Zingone A., Gambi M.C. and Streftaris N. (2010) Alien species in the Mediterranean Sea by 2010. A contribution to the application of European Union's Marine Strategy Framework Directive (MSFD). Part I. Spatial distribution. Mediterranean Marine Science $11,381-493$.

Zibrowius H. (1991) Ongoing modification of the Mediterranean marine flora and fauna by the establishment of exotic species. Mésogée 51 , $83-107$.

and

Zibrowius H. (2002) Assessing scale and impact of ship transported alien fauna in the Mediterranean? CIESM Workshop Monographs 20, 63-68.

\section{Correspondence should be addressed to:}

A.A. Ramos-Esplá

Departamento de Ciencias del Mar y Biologia Aplicada Universidad de Alicante, 03080, Alicante, Spain email: alfonso.ramos@ua.es 